\title{
ORAL ACUTE TOXICITY AND RED BLOOD CYTOTOXICITY OF THE MEDICINAL HALOPHYTE LIMONIASTRUM GUYONIANUM LEAF EXTRACT
}

\author{
ABDERRAHIM BENKHALED ${ }^{1}$, ABDERRAHMANE SENATOR ${ }^{2}$, AMEL BOUDJELAL $^{1}$, \\ ABDELHAKIM KHENICHE ${ }^{1}$, AMINE BELBAHI ${ }^{1,3}$, YASSINE RÉGGAMI ${ }^{1}$, ASMA CHEBIKA $^{1}$, \\ WALID SALHI ${ }^{1}, \mathrm{KHODIR}$ MADANI $^{2}$, GIUSEPPE RUBERTO ${ }^{4 *}$ \\ ${ }^{1}$ Department of Microbiology and Biochemistry, Faculty of Sciences, M'sila University, M'sila, Algeria \\ ${ }^{2}$ Laboratory of Applied Biochemistry, Faculty of Natural and Life Sciences, Ferhat Abbas-Setif University, Setif, Algeria \\ ${ }^{3}$ Laboratoire de Biomathématique, Biophysique, Biochimie, et Scientométrie, Faculté des Sciences de la Nature et de la Vie, \\ Université de Bejaia, 06000 Bejaia, Algérie \\ ${ }^{4}$ Istituto del CNR di Chimica Biomolecolare, Via Paolo Gaifami, 18 - 95126 Catania, Italy
}

*corresponding author: giuseppe.ruberto@icb.cnr.it

Manuscript received: November2019

\begin{abstract}
Limoniastrum guyonianum is widely used traditionally in North Africa as decoction or infusion to treat various types of infections. However, safety assessment of this medicinal halophyte is still lacking. The aim of this study was to investigate the safety of the aqueous leaves extract by determining the oral acute toxicity effect on adult mice and cytotoxicity on human red blood cells. No mortality or specific toxic signs were observed. The LD 50 can then be estimated to be greater than 5000 $\mathrm{mg} / \mathrm{kg}$. The recommended dose used in humans will be a maximum of $500 \mathrm{mg} / \mathrm{kg}$. Histopathological examinations showed alterations that affected both renal and hepatic tissues, being the kidneys more sensitive. Indeed, glomerular necrosis appeared with the first ingested dose $(1000 \mathrm{mg} / \mathrm{kg} \mathrm{bw})$. In contrast, focal hepatocyte necrosis was noticeable only at a concentration of $5000 \mathrm{mg} / \mathrm{kg}$ bw. The cytotoxic study showed a slight haemolysis of $13.52 \%$ which demonstrate that the extract does not express a haemolytic activity. Hence, the extract can be safety utilized in folkloric popular medicine as an oral anti-infective.
\end{abstract}

\section{Rezumat}

Limoniastrum guyonianum este utilizată tradițional pe scară largă în Africa de Nord, sub formă de decoct sau infuzie pentru tratarea diferitelor tipuri de infecții. Cu toate acestea, evaluarea siguranței acestei plante halofite nu a fost încă studiată. Scopul acestui studiu a fost de a investiga siguranța utilizării extractului apos de frunze prin determinarea toxicitații acute la şoarecii adulți şi a citotoxicității asupra globulelor roșii umane. Nu au fost observate semne toxice specifice. DL50 estimată a fost mai mare de $5000 \mathrm{mg} / \mathrm{kg}$. Doza recomandată la om se estimează la maximum $500 \mathrm{mg} / \mathrm{kg}$. Examenele histopatologice au arătat modificări care au afectat atât țesuturile renale, cât și hepatice, rinichii fiind mai sensibili. Necroza glomerulară a apărut o dată cu prima doză ingerată (1000 mg/kg corp). În schimb, necroza hepatocitară focală a fost vizibilă doar la o concentrație de $5000 \mathrm{mg} / \mathrm{kg}$ corp. Studiul citotoxic a arătat o ușoară hemoliză, care demonstrează că extractul nu exprimă o activitate hemolitică. Prin urmare, extractul poate fi utilizat în siguranță ca antiinfecțios oral.

Keywords: Limoniastrum guyonianum, acute toxicity, cytotoxicity, human red blood cells

\section{Introduction}

Natural products play a dominant role in the development of novel drug leads for the treatment and prevention of diseases. Herbs have recently attracted attention as health beneficial foods and as source materials for drug development. They offer a potential natural health care approach that focuses on protecting and restoring health [33].

Limoniastrum guyonianum is medicinal halophyte, endemic to northern Sahara (Algeria, Tunisia), omnipresent in the salty lands of Sebkhas and Chotts and in the Sahara [9]. In Algeria, L. guyonianum is called "Zeïta". The traditional pharmacological uses of
L. guyonianum in the treatment of different pathologies are widely practiced in Algeria and other countries of North Africa. In Algeria, peoples of the southern "Aurès" region use the aerial part of the plant as a decoction against bronchitis and inflammation of the throat [1]. In the region of Ouargla (South-East), the plant is used either alone, or in combination with other plants in decoction, or powder to treat skin burns and wounds, metabolic and respiratory diseases [18]. The tannins of the galls have tonic properties associated with Henné [11], whereas roots decoction is used as depurative $[12,16]$. In southern Tunisia, infusions of leaves and galls are used as anti-dysenteric and against bacterial (bronchitis) or parasitic infections 
[9]. In the region of Tafilalet (Morocco), decoction of leaves and galls is also used for the treatment of diarrhoea [15].

A literature survey allowed us to identify the bioactive molecules of $L$. guyonianum responsible for the observed pharmacological activities, which can be associated to the traditional uses of plant. The active compounds are in most cases polyphenols, flavonoids, tannins and phenolic acids. These studies demonstrated antioxidant [14, 24, 41-43], antimicrobial [5, 7, 42], immunomodulatory [24], antimutagenic, antiproliferative, pro-apoptotic and anticancer activities [25-27, 45]. Furthermore, the aqueous extract of $L$. guyonianum proved to be more efficient than vitamin $\mathrm{C}$ pre-treatments in attenuating nickel induced haematological alterations [6].

Three powerful flavonoids with antioxidative property (gallocatechin, epigallocatechin and epigallocatechin3-O-gallate) were isolated from L. guynianum [41]. Other phenolic compounds such as catechin and its derivatives, previously cited as antioxidant [40], were also detected [41]. Trabelsi et al. [43] have isolated a new dimer of phenolic acid amide with strong antioxidant activity which can be used in the pharmaceutical and food industries due to their antioxidant properties. Krifa et al. [24] have demonstrated the immunomodulatory effect of the aqueous extract of galls of L. guyonianum. This effect could be attributed, in part, to its cytoprotective effect exerted by some of its antioxidant components, such as flavonoids. These compounds can potentially modulate the functions of immune cells in physiological and pathological conditions.

L. guyonianum extracts exhibited an important and variable antibacterial activity. Inhibitory capacity against these pathogens was likely due to the richness of these extracts in phenolic compounds [42]. Methanolic, chloroform and petroleum ether extracts of $L$ guyonianum were found to be most potent against Pseudomonas aeruginosa and Staphylococcus aureus [7].

Despite the widespread use of medicinal plants, few scientific studies have been undertaken to ascertain the safety and efficacy of traditional remedies [17]. Indeed, it is important to note that many medicinal plants have also been reported to be toxic to both humans and animals. Therefore, it should be emphasized that the traditional use of any plant for medicinal purposes, by no means, guarantees the safety of such plant. Evaluation of toxic properties of a substance is crucial when considering for public health protection. Toxicity screening models provide important preliminary data to help select natural remedies with potential health beneficial properties for future work [33]. However, there is no information or evidence available concerning the possible toxicity that $L$. guyonianum may cause to the consumers. Moreover, no toxicological studies on this medicinal plant have been performed. Considering both the ethnobotanical and pharmacological applications of $L$. guyonianum, the aim of this study was to investigate the safety of the aqueous leaves extract of the plant by determining its possible oral acute toxicity on adult mice and cytotoxicity test on human red blood cells.

\section{Materials and Methods}

\section{Plant material}

L. guyonianum was collected from Bir-Alarbi, M'sila, Algeria, at the flowering stage. The plant was identified by Dr. Sarri Djamel, Department of Natural Sciences and Life, Faculty of Sciences, M'sila University, Algeria. The voucher was deposited at the same Department. The leaves were cleaned then separated and dried at room temperature until obtaining a constant weight. Dried leaves were ground to a fine powder and stored in air-tight bottles until use.

Aqueous extract preparation

Approximately $20 \mathrm{~g}$ of the powdered sample were added to $200 \mathrm{~mL}$ of boiling distilled water for 4 hours with continuous stirring [6]. The extract was filtered, and then evaporated to dryness at $55^{\circ} \mathrm{C}$ in ventilated oven. This operation was performed several times in order to obtain a manageable quantity of dry aqueous extract to carry out the toxicity study.

\section{Oral acute toxicity}

Animals

Acute oral toxicity test was performed as per OECD guidelines 420 [31]. Experiments were carried out using healthy young adult female Swiss albino mice, nulliparous, non-pregnant and weighing $26-32 \mathrm{~g}$. These animals were obtained from Pasteur Institute of Algiers. Mice were placed in plastic cages with free access to food and water. Litter of wood chips was renewed every 2 days. The mice were acclimated to laboratory conditions for 15 days before experimentation. They were fed with croquettes from the National Company of cattle diet (ONAB) of El Kseur (Bejaia). Female mice were chosen because of their greater sensitivity to treatment [19]. All protocols used in this study were approved under the CNEPRU DO1N01UN280120150001 by the Ethical Committee of Directorate General for Scientific Research and Technological Development at Algerian Ministry of Higher Education and Scientific Research.

\section{Constitution of groups and treatment of mice}

After acclimatization 4 groups of 10 mice each were constituted. The mice were deprived of food $18 \mathrm{~h}$ before the administration of the extract to stop any digestive food interaction. Three doses of the aqueous extract 1000, 2000 and $5000 \mathrm{mg} / \mathrm{kg}$ bw were administered as a single dose orally at a rate of $0.5 \mathrm{~mL} / 100 \mathrm{~g}$ of body weight to the 3 groups of treated mice, the $4^{\text {th }}$ group control received distilled water.

Symptomatic disorders

After treatment, the animals were maintained under the same conditions of temperature, lighting and feeding. 
The treated mice were observed individually every 30 minutes for 6 hours, during the first day and every day for 14 days according to the guidelines of Conseil Canadien de Protection des Animaux [13] and Organization for Economic Co-operation and Development [30]. During this period, all the behavioural and symptomatic variations have been observed, with particular attention to external physical aspects (appearance and hair loss), behavioural changes (posture, scraping, aggressiveness, sensitivity noise and light, hyper-salivation, etc.), and measurable clinical signs (changes in heart and respiratory rhythms, abdominal contraction, diarrhoea).

\section{Determination of lethal and tolerated doses}

Among the aims of this study is the determination of the Maximum Tolerated Dose (MTD), which is the maximum dose with no observable toxic effect, the Minimum Mortal Dose (MDI) that kills an animal from the batch treated, the lethal dose for $50 \%$ of animals $\left(\mathrm{LD}_{50}\right)$ and the lethal dose for $100 \%$ of animals $\left(\mathrm{LD}_{100}\right)$. The value of the $\mathrm{LD}_{50}$ makes it possible to classify the extract on the toxicity scale of Hodge and Sterner [21] for mice and rats. The $\mathrm{LD}_{50}$ of the aqueous leaf extract of $L$. guyonianum is not yet determined.

Body and relative organ weights

Body weights were measured before starting the experimentation and every two days thereafter. At the end of the experiment, all surviving animals fasted overnight and sacrificed by decapitation. The organs such as liver, heart and kidneys were excised and weighed.

\section{Serum biochemical parameters}

In order to detect possible toxic effects of the extract, the blood of surviving mice after 14 days of experimentation was recovered to explore some biochemical parameters related to liver function (transaminases, alkaline phosphatase, serum total protein and albumin) and renal functions (creatinine, urea and uric acid). These analyses were performed at the central laboratory of the University Hospital Center of Setif using an automatic biochemistry analyser (Technicon, RA 1000).

\section{Histological examinations}

The excised livers and kidneys were washed in normal saline and fixed immediately in $10 \%$ formalin, dehydrated with upgraded ethanol series, embedded in paraffin, cut into $5 \mu \mathrm{m}$ thick sections and stained with haematoxylin-eosin dye for photo-microscopic observation. Histopathological examinations of the organs of the treated mice were compared with the control group.

Cytotoxic study (Haemolytic test)

The cytotoxicity study was performed on human red blood cells (RBCs) from healthy donors. The haemolysis rate of RBCs was studied both by measuring the absorbance of released haemoglobin $(\mathrm{Hb})$ and by counting residual cells after haemolysis. To test the haemolytic effect of our extract, 7 concentrations (5, $10,15,25,50,100$ and $200 \mathrm{mg} / \mathrm{mL}$ ) were prepared in isotonic phosphate buffer solution (PBS) at $\mathrm{pH}$ 7.4. The blood of healthy volunteers $(3 \mathrm{~mL})$ was freshly collected in heparinized tubes. The RBCs were separated from the plasma by centrifugation at $4500 \mathrm{rpm}$ for 5 min. The pellet was washed 3 times with 5 volumes of PBS. During the last wash, the erythrocytes were centrifuged at $4500 \mathrm{rpm}$ for $3 \mathrm{~min}$ to obtain a packaged cell preparation. The washed cells were re-suspended in a final volume of $20 \mathrm{~mL}$ of PBS [46].

The haemolytic effect of the aqueous extract was evaluated according to the method described by Powell et al. [34]. Aliquots of $540 \mu \mathrm{L}$ of the erythrocyte suspension were mixed with $60 \mu \mathrm{L}$ of PBS solution containing the extract at different concentrations. The samples were mixed gently and incubated at $37^{\circ} \mathrm{C}$ for $35 \mathrm{~min}$ in a water bath with gentle agitation. The tubes were then cooled in an ice bath for $5 \mathrm{~min}$ and then centrifuged at $4500 \mathrm{rpm}$ for $5 \mathrm{~min}$. Volumes of $300 \mu \mathrm{L}$ of supernatant were diluted in $2700 \mu \mathrm{L}$ of PBS. The solution was used to monitor the leakage of haemoglobin by measuring the absorbances at $576 \mathrm{~nm}$ against a positive control (total haemolysis with distilled water). PBS was used as a negative control ( $0 \%$ lysis).

The haemolytic effect can also be evaluated by counting the residual RBCs after treatment with the extract. Cell count was performed on Thoma cell. After haemolysis, the pellet of each assay was suspended again in PBS for a second enumeration to determine the number of un-haemolysed RBCs [46].

The test was performed in triplicate for each concentration. The haemolysis rate $\left(\mathrm{H}_{\mathrm{Hb}}\right)$ was calculated according to the following formula:

$$
\mathrm{H}_{\mathrm{Hb}}(\%)=\left[\mathrm{A}_{\mathrm{t}} / \mathrm{A}_{\mathrm{c}}\right] \times 100,
$$

where: $A_{t}=$ absorbance of the test, $A_{c}=$ absorbance of positive control.

The rate of cellular haemolysis $\left(\mathrm{H}_{\mathrm{C}}\right)$ can also be calculated by cell count according to the following formula:

$$
\mathrm{H}_{\mathrm{C}}(\%)=\left[\mathrm{C}_{\mathrm{i}} / \mathrm{C}_{\mathrm{f}}\right] \times 100,
$$

where: $\mathrm{C}_{\mathrm{i}}=$ number of cells before haemolysis, $\mathrm{C}_{\mathrm{f}}=$ number of cells after haemolysis.

Statistical Analysis

All values are expressed as mean \pm SEM. Comparisons between groups were performed using one-way analysis of variance (ANOVA) followed by Tukey's multiple comparison tests using Graph Pad. Prism 5 statistical software. A p value of $<0.05$ was considered significant. 


\section{Results and Discussion}

\section{Oral acute toxicity}

General signs

During this study it was not observed mortality or specific toxic signs after oral administration of the extract at all doses used apart from a hair changes and decreased activity of mice that received a dose of $5000 \mathrm{mg} / \mathrm{kg}$ bw and returned to normal soon thereafter. In addition, there were no respiratory, nervous, cutaneous or gastrointestinal symptoms. According to the toxicity scale of Hodge and Sterner [21] for mice and rats, the aqueous extract of $L$. guyonianum can be classified as a non-toxic substance because no mouse in the group receiving $5000 \mathrm{mg} / \mathrm{kg}$ was dead. This suggests that this dose represents the non observable toxic effect level (NOAEL), which is a primary criterion in clinical trials since it serves as a basis for calculating the first dose used in humans. This dose was calculated by dividing the NOAEL on the Safety Factor which is greater than or equal to 10 [2]. The recommended dose will be a maximum of $500 \mathrm{mg} / \mathrm{kg}$. Considering the average human blood volume of $60 \mathrm{~mL} / \mathrm{kg}$, the dose circulating in the body will average $8.33 \mathrm{mg} / \mathrm{mL}$.

Weight evolution

The variation of the mice body weight during the 14 days of experimentation was noted every 2 days and at the same hour which makes it possible to follow the weight evolution of the treated and control animals. On day 0 , mice have homogeneous weights of $26 \mathrm{~g}$ to $32 \mathrm{~g}$. During the 14 days the progress of weight seemed normal, demonstrating the insensitivity of animals to the extract. The ingestion of the extract caused no significant change in body weight of mice compared to controls throughout the test period (Figure 1).

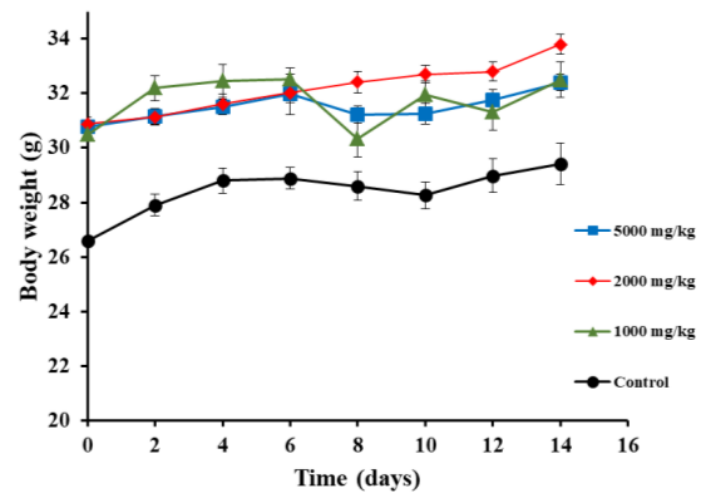

Figure 1.

Evolution of the body weight of the control mice and treated with the aqueous extract of the leaves of $L$. guyonianum at doses 1000, 2000 and $5000 \mathrm{mg} / \mathrm{kg}$ bw after 14 days of treatment

Each value represents the mean $(n=10) \pm$ SEM

\section{Relative weight of organs}

After animal sacrifice, the liver, kidneys and heart were collected for macroscopic examination. The size and shape of these organs were found to be normal and no morphological changes were observed, and this can be considered an index of lack of pathologies. Since the wellness of an organ can be correlated to its relative weight (weight of the organ/weight of the mouse $\times 100$ ), being the hypertrophy of an organ means a beginning of dysfunction. No significant increase $(p \leq 0.05)$ in the relative weight of the kidneys and livers was observed for the 3 groups treated with 1000, 2000 and $5000 \mathrm{mg} / \mathrm{kg}$ bw (Figure 2).

A
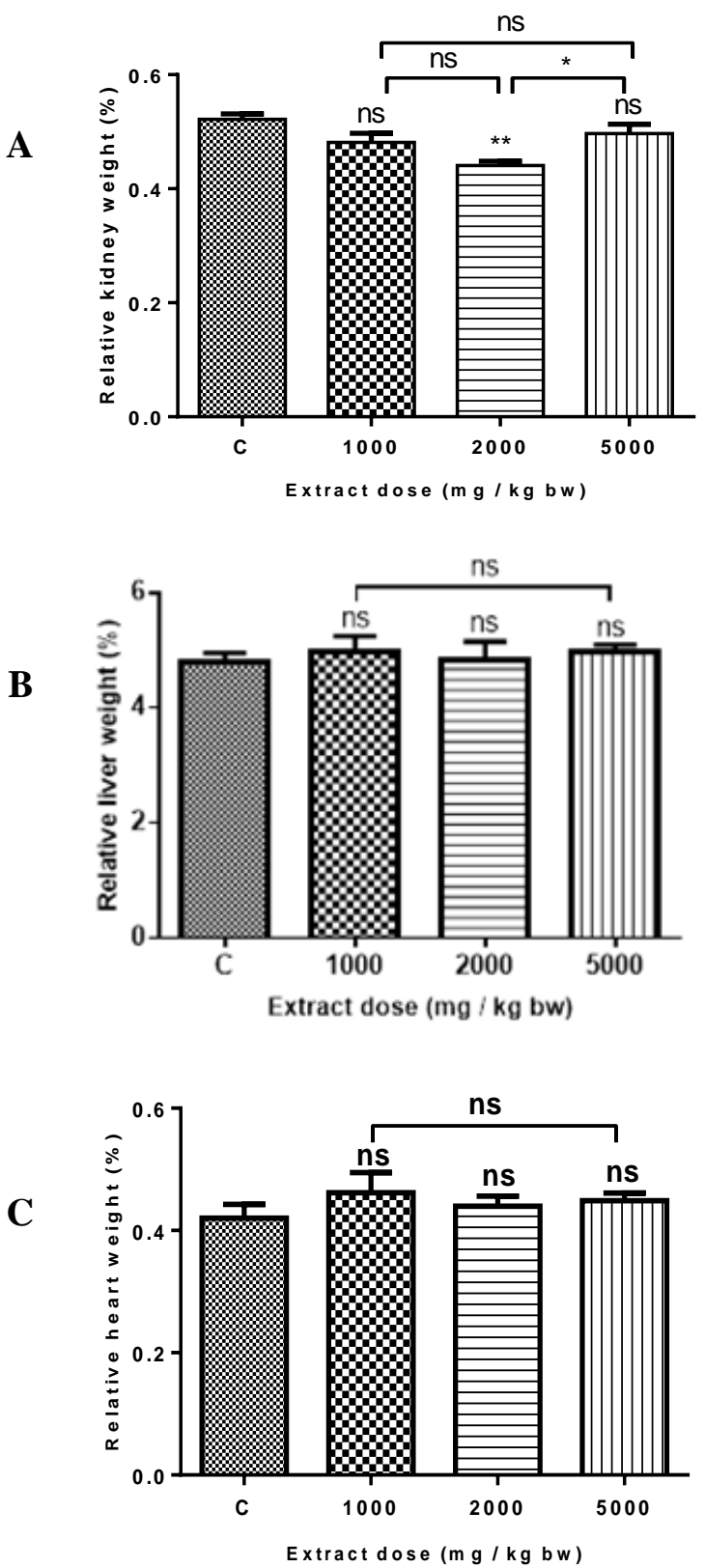

Figure 2.

Variation of the relative weights of kidneys (A), liver (B) and heart (C) of the control mice and treated with 1000,2000 and $5000 \mathrm{mg} / \mathrm{kg}$ bw of the aqueous extract of leaves of $L$. guyonianum after 14 days of treatment

Each value represents the mean $(n=10) \pm$ SEM 
The clinical signs facilitate the interpretation of the results of the toxicological studies. Indeed, our mice never showed signs of toxicity or a decline in zootechnical performance. According to the globally harmonized classification system of the OECD [30] and since the $\mathrm{LD}_{50}$ has been estimated at more than $5000 \mathrm{mg} / \mathrm{kg}$ bw, the aqueous extract of leaves of $L$. guyonianum can be classified under category 5 , therefore considered a non-toxic oral substance.

\section{Biochemical parameters}

The assessment of the extent and severity of poisoning by medicinal plants or their extracts is primarily based on the prospection of liver and renal markers. To ensure non-toxicity of the aqueous extract, various biochemical parameters were measured at the end of the experiment (D14) and compared to controls. The results obtained are listed in Table I.

Variation of the biochemical parameters of control mice and treated with the aqueous extract of leaves of L. guyonianum at doses $1000,2000,5000 \mathrm{mg} / \mathrm{kg}$ bw after 14 days of treatment

\begin{tabular}{|l|c|c|c|c|}
\hline \multirow{2}{*}{ Biochemical markers } & \multicolumn{4}{|c|}{ Extract dose $(\mathrm{mg} / \mathrm{kg} \mathrm{bw})$} \\
\cline { 2 - 5 } & Controls & 1000 & 2000 & 5000 \\
\hline ALAT (U/L) & $65.31 \pm 1.94^{\mathrm{a}}$ & $51.80 \pm 5.42^{\mathrm{a}}$ & $46.75 \pm 3.63^{\mathrm{a}}$ & $48.80 \pm 6.17^{\mathrm{a}}$ \\
\hline ASAT (U/L) & $275.35 \pm 8.93^{\mathrm{a}}$ & $251.80 \pm 23.00^{\mathrm{a}}$ & $213.33 \pm 13.38^{\mathrm{a}}$ & $230.75 \pm 12.73^{\mathrm{a}}$ \\
\hline PAL (U/L) & $77.75 \pm 8.05^{\mathrm{a}}$ & $68.40 \pm 6.47^{\mathrm{a}}$ & $65.10 \pm 9.52^{\mathrm{a}}$ & $60.87 \pm 2.01^{\mathrm{a}}$ \\
\hline Total Proteins (g/L) & $63.08 \pm 5.55^{\mathrm{a}}$ & $53.66 \pm 3.48^{\mathrm{ab}}$ & $44.43 \pm 6.49^{\mathrm{ab}}$ & $44.76 \pm 1.07^{\mathrm{b}}$ \\
\hline Albumin (g/L) & $29.60 \pm 0.29^{\mathrm{a}}$ & $29.21 \pm 0.86^{\mathrm{a}}$ & $29.00 \pm 0.31^{\mathrm{a}}$ & $30.82 \pm 0.97^{\mathrm{a}}$ \\
\hline Uric acid (mg/L) & $84.57 \pm 4.75^{\mathrm{a}}$ & $65.40 \pm 3.20^{\mathrm{ab}}$ & $61.41 \pm 7.44^{\mathrm{b}}$ & $60.6 \pm 2.16^{\mathrm{b}}$ \\
\hline Urea (g/L) & $0.49 \pm 0.02^{\mathrm{a}}$ & $0.47 \pm 0.04^{\mathrm{a}}$ & $0.51 \pm 0.04^{\mathrm{a}}$ & $0.42 \pm 0.02^{\mathrm{a}}$ \\
\hline Creatinine (mg/L) & $4.32 \pm 0.05^{\mathrm{a}}$ & $4.47 \pm 8.93^{\mathrm{a}}$ & $5.14 \pm 0.07^{\mathrm{b}}$ & $5.64 \pm 0.03^{\mathrm{c}}$ \\
\hline
\end{tabular}

Each value represents the mean $(\mathrm{n}=10) \pm \operatorname{SEM}(\mathrm{p}<0.05$, Tukey test). Values with different letters on the same line are significantly different.

\section{Markers of hepatic function}

Hepatocyte involvement causes the release of enzymes into the extracellular compartment, then some liver enzymes have been tested, namely alanine aminotransferase (ALAT), aspartate aminotransferase (ASAT) and alkaline phosphatase (ALP). The increase in transaminases reflects cell damage, particularly in the liver [22, 36].

ALAT is cytosolic localization, while ASAT is mainly mitochondrial [3]. Given its specificity and the availability of the assay, ALAT is the reference for biomarkers of liver damage [32]. Increased serum ALAT activity is typically associated with cell membrane damage and leakage of hepatocyte enzymes [44]. A moderate increase ( 2 times) is more in favour of a chronic condition or cholestasis [28]. Because of its presence both in the liver, heart and skeletal muscle, plasma concentration increase of ASAT activity can be linked to muscle inflammation. However, because of its predominantly mitochondrial distribution in hepatocytes and its very short half-life, it is often considered a reliable marker of the severity and persistence of hepatic necrosis [28].

The analysis of transaminase levels in experimental mice showed a downward trend, suggesting that the extract did not affected these liver parameters. This extract probably has no hepatotoxic effect on mice. The ALP is another enzyme that can be used to evaluate liver function. In addition to liver damage (hepatitis, abscess, etc.), the ALP assay can detect cholestasis and biliary obstructions. ALP is a not very specific enzyme, given the existence of numerous isoenzymes in bone, placental and renal tissues [32]. The results showed a decrease in its activity for the
3 doses tested, but compared to the control group this decrease was not significant. The absorption of the aqueous extract of $L$. guyonianum would not cause cytolysis, and the plant appears to be well tolerated. In addition to its role of detoxification, the liver is also the site of the synthesis of several proteins $(90 \%$ of total proteins) essential to the general metabolism, in particular albumin [8]. Following cell injury, the synthesis capacity is reduced and the concentration of these constituents decreases. A decrease in protein levels could mean severe liver dysfunction (cirrhosis). Our study revealed that the extract at 1000, 2000 and $5000 \mathrm{mg} / \mathrm{kg}$ bw in single doses did not show a significant difference for total proteins. Similarly, administration of the extract caused no significant change in serum albumin levels in mice compared to their controls. The fluctuations noted are minimal or even negligible. The results of the protein assay reflect a normal protein metabolism. In conclusion, the biochemical markers of liver function have been slightly modified indicating the absence of hepatotoxicity of the extract.

Markers of kidney function

Blood urea and creatinine are considered to be excellent markers of renal function. The extract did not induce any significant changes in plasma urea concentration in the treated mice compared to the control group. Instead, mean values of serum uric acid concentrations were significantly different and ranged from $84.57 \mathrm{mg} / \mathrm{L}$ in control mice to $65.4,61.4$ and $60.6 \mathrm{mg} / \mathrm{L}$ in mice treated with 1000, 2000 and $5000 \mathrm{mg} / \mathrm{kg}$ bw of extract, respectively. In parallel, the extract has a significant effect in increasing serum creatinine for 
doses of 2000 and $5000 \mathrm{mg} / \mathrm{kg}$ bw In sum, the results showed that the extract did not appear to be nephrotoxic. Creatinine and uric acid were selected as serum biomarkers of renal function, and their levels increased in a dose-dependent manner in the serum. The mice were "able" to reveal these metabolic disruptions, without presenting clinical signs, at least during the 14 days of study. In some cases, metabolic disruptions affecting the target organ may take longer to set in, or may show greater amplitude, resulting in disruption of the body's homeostatic balance. This can then result in clinical or biochemical manifestations that may appear later. Sometimes these metabolic disruptions remain tenuous and are unable to cause clinical disorders.

\section{Histopathological study}

The histopathological study occupies a preponderant place and constitutes an unavoidable step in the study of the toxicity. The liver and kidneys are the preferred targets in these studies. Histological examination was performed under photonic microscopy at 100x magnification.

\section{Liver histopathology}

Figure 3 shows histological sections of the liver of treated animals. The control group exhibits overall normal liver architecture marked by the presence of hepatocyte trabeculae arranged radially around a centrilobular vein, a portal vein, a bile duct and a hepatic artery (Figure 3A). In contrast, the hepatic architecture of the mice treated with $1000 \mathrm{mg} / \mathrm{kg}$ bw is altered with irregular and bloated hepatocytes associated with sinusoidal congestions and the portal system (Figure 3B). The mice treated with $2000 \mathrm{mg} / \mathrm{kg}$ bw of extract showed, in addition to the ballooning of the hepatocytes, a congestion of the portal vein associated with peria-centro-lobular dilatation of the sinusoidal capillaries (Figure 3C). It is important to note that alterations of liver tissue were more apparent and more marked in the group treated with the extract at $5000 \mathrm{mg} / \mathrm{kg}$ bw (Figure 3D). In these mice, we observed a severe sinusoidal dilatation around the centrilobular vein associated with distended hepatocytes and hepatocellular focal necrosis.
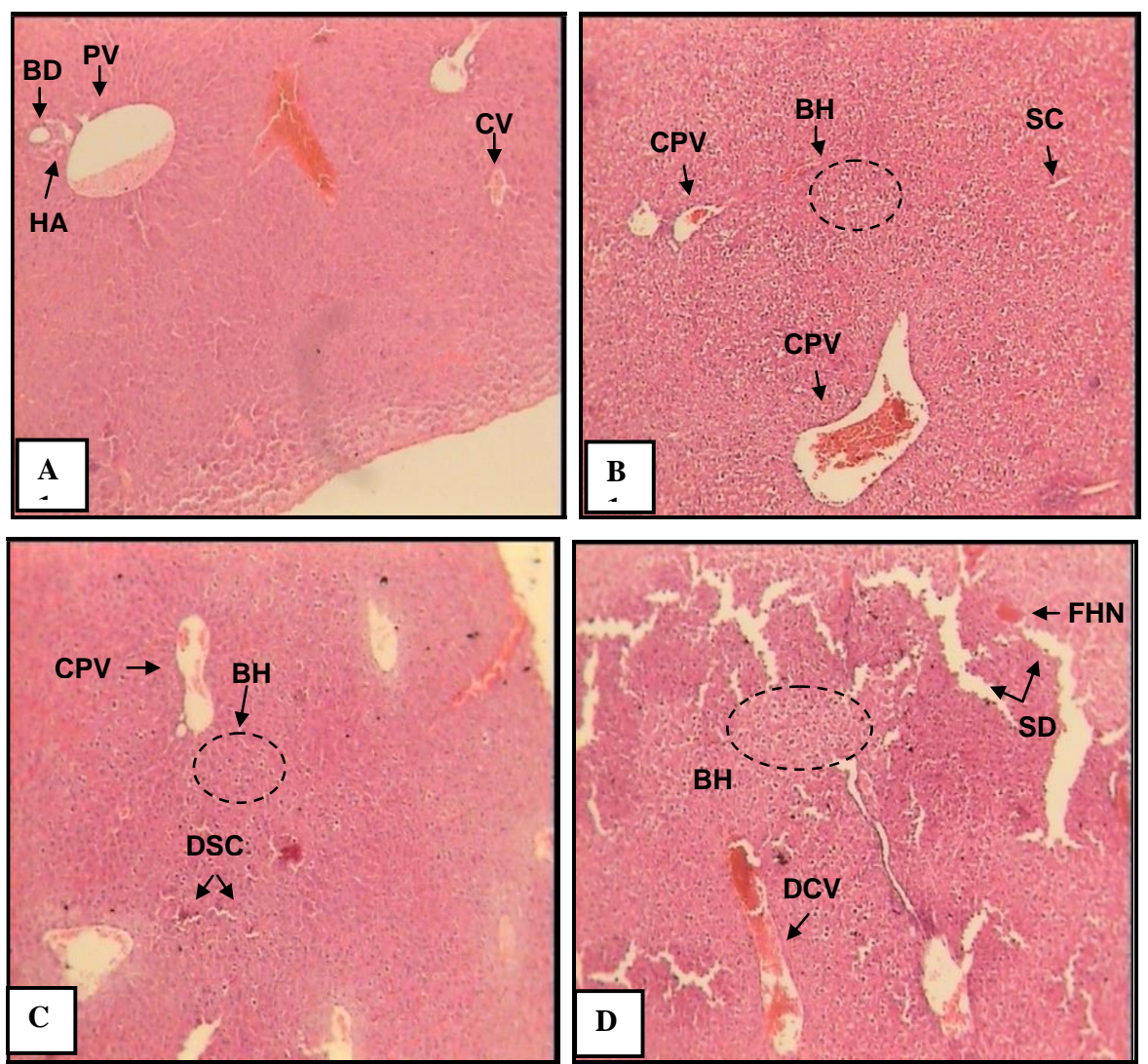

Figure 3.

Histological comparison of hepatic tissues in normal and L. guyonianum - treated mice. Photomicrographs showing sections from the centre of the largest liver lobes tissues of control mice (A) and experimental animals treated with aqueous leaves extract of L. guyonianum at doses 1000 (B), 2000 (C) and $5000 \mathrm{mg} / \mathrm{kg} \mathrm{bw} \mathrm{(D)}$ Examinations were carried out at 100x magnifications with haematoxylin-eosin's stain. HA = Hepatic artery; $\mathbf{B D}=$ Bile duct; $\mathbf{C V}=$ Centro-lobular vein; $\mathbf{D C V}=$ Dilated centro-lobular vein; $\mathbf{P V}=$ Portal vein; $\mathbf{C P V}=$ Congestion of portal vein; $\mathbf{D S C}=$ Dilation of sinusoidal capillaries; $\mathbf{S D}=$ Sinusoidal dilatation; $\mathbf{S C}=$ Sinusoidal congestion; $\mathbf{B H}=$ Balloonization of hepatocytes; $\mathbf{F H N}=$ Focal hepatocytes necrosis 


\section{Histopathology of the kidneys}

Microscopic observation of the renal tissue of control group mice (Figure 4A) allowed us to see normal cortical and medullary areas with the presence of well-defined uniform membrane glomeruli associated with normal tubules. The glomeruli appear as dense rounded structures, surrounded by a clear narrow space, Bowman's space. A large number of tubes, mainly proximal convoluted tubes, surround these glomeruli. The mice treated with $1000 \mathrm{mg} / \mathrm{kg}$ bw of extract (Figure 4B) revealed an altered renal architecture in which a relatively small number of glomeruli are dilated or even necrotic. In addition, we observed vascular congestions, a tubular necrosis in phase of installation (degeneration of tubular epithelial cells with the loss of the brush border of the proximal tubes) and the presence of cellular debris in the damaged tubules. At higher extract dosage (the mice treated with 2000 $\mathrm{mg} / \mathrm{kg} \mathrm{bw}$ ) (Figure 4C), the dilated glomeruli increased in number and shape, similarly acute tubular necrosis was more pronounced giving lesions characterized by the absence of epithelium. However, the basement membrane remains intact and maintains its integrity. In mice treated with $5000 \mathrm{mg} / \mathrm{kg}$ bw (Figure 4D), congestion with leukocyte infiltration associated with degeneration and tubular necrosis were observed, in addition to the presence of several foci of glomerular necrosis.
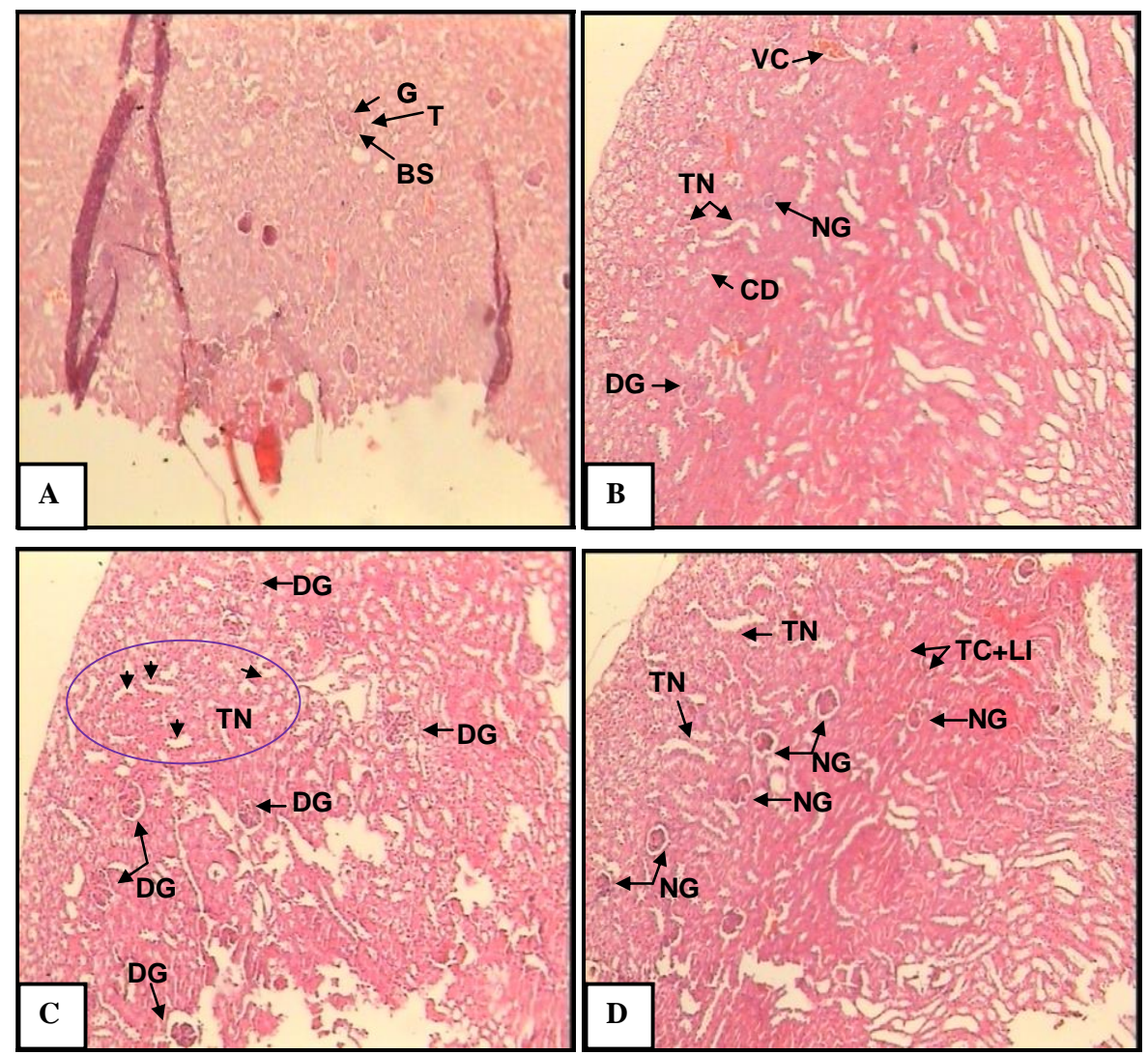

Figure 4.

Histological comparison of renal tissues in normal and L. guyonianum-treated mice. Photomicrographs showing sections from the renal cortex tissues of control mice (A) and experimental animals treated with aqueous leaves extract of L. guyonianum at doses 1000 (B), 2000 (C) and $5000 \mathrm{mg} / \mathrm{kg}$ bw (D).

Examinations were carried out at 100x magnifications with haematoxylin-eosin's stain. $\mathbf{G}=$ Glomerulus; $\mathbf{T}=$ Tubule; $\mathbf{B S}=$ Bowman's Space $; \mathbf{D G}=$ Dilated glomerulus $\mathbf{N G}=$ Necrotized Glomerulus $; \mathbf{V C}=$ Vascular congestion; $\mathbf{T N}=$ Tubular necrosis $\mathbf{C D}=$ Cell Debris; $\mathbf{T C}+\mathbf{L I}=$ Tubular congestion + Leukocyte infiltration

Histopathological examinations showed alterations affecting both renal and hepatic tissue. However, the kidneys were more sensitive to the extract. Indeed, glomerular necrosis appeared with the first ingested dose $(1000 \mathrm{mg} / \mathrm{kg} \mathrm{bw})$. In contrast, focal hepatocyte necrosis was noticeable only at a concentration of $5000 \mathrm{mg} / \mathrm{kg}$ bw These attacks appear dose-dependent and are the result of short exposure to high doses of extract.
Toxicity study of this medicinal halophyte is still lacking. In addition, there are few works devoted to studying the toxicity of neighbouring species. Therefore, little is known about their toxicity and safety issues. The hydroacetonic extract of $L$. brasiliense rhizomes did not cause any apparent clinical changes in the mice during the 14 days of observation. In addition, the calculated LD $\mathrm{LD}_{50}$ was $4800 \mathrm{mg} / \mathrm{kg}$ [4]. L. sinense root extracts expressed hepatoprotective activity [39]. 
The ethanolic extract of Plumbago rosea has been studied to evaluate its acute toxicity in mice. The $\mathrm{LD}_{50}$ (after 24 hours) values of the extract were 239.88 and $1148.15 \mathrm{mg} / \mathrm{kg}$ bw for the intraperitoneal and oral routes, respectively. Oral doses above $1250 \mathrm{mg} / \mathrm{kg}$ bw produced severe diarrhoea [37]. The results of the acute oral toxicity study of the non-alcoholic extract of Plumbago zeylanica roots showed no deaths and no clinical signs of toxicity after increasing doses up to $5000 \mathrm{mg} / \mathrm{kg}$ bw in Swiss albino rats. $\mathrm{LD}_{50}$ was found to be greater than $5000 \mathrm{mg} / \mathrm{kg}$ bw [35]. Similarly, the study of the orally acute toxicity of the aqueous extract from the leaves of Guibourtia tessmannii in mice showed no death and no clinical signs of toxicity during the fourteen days of study.

Cytotoxic study

The cytotoxicity test of the aqueous extract was performed on a universal model of human red blood cells (RBCs) from healthy donors. The amount of haemoglobin released and by extension the proportion of affected RBCs can be determined spectrophotometrically. The test was confirmed by counting residual RBCs after treatment with the extract.

The haemolytic potential test was controlled by the blood without haemolytic agent and blood completely haemolysed by a known haemolytic agent. In the case of our study, distilled water was used as a positive control allowing total haemolysis. PBS was used as a negative control ( $0 \%$ lysis). The haemolysis test was performed for a wide range of concentrations ranging from 5 to $200 \mathrm{mg} / \mathrm{mL}$.

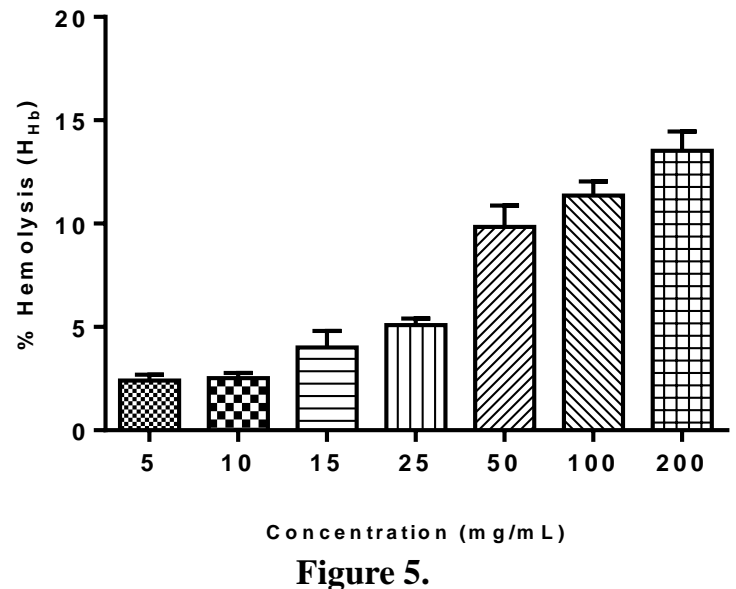

Haemolytic effect of aqueous leaf extract of

L. guyonianum measured by $\mathrm{H}_{\mathrm{b}}$ release (absorbance at $576 \mathrm{~nm}$ )

Different letters represent significant differences $\mathrm{p}<0.05$ (Tukey test)

These results (Figure 5) proved that the aqueous extract induced RBCs haemolysis in a dose-dependent manner. At the lowest concentrations $(5,10$ and $15 \mathrm{mg} / \mathrm{mL})$, the extract caused slight haemolysis $<5 \%$ close to the negative control $(2.4,2.5$ and $4.0 \%$ respectively). At the concentration of $50 \mathrm{mg} / \mathrm{mL}$, the haemolysis rate did not exceed $9.8 \%$. At the highest used dose (200 $\mathrm{mg} / \mathrm{mL}$ ), the haemolysis rate increased slightly but remains low and did not exceed $13.52 \%$.

Generally, the haemolytic potential test results in a $50 \%$ haemolytic concentration $\left(\mathrm{IC}_{50}\right)$. However, in our case it was not possible to determine this $\mathrm{IC}_{50}$ for all the concentrations used, since the percentage of haemolysis did not exceed $13.52 \%$. It is important to note that the results of haemolysis levels measured by cell count $\left(\mathrm{H}_{\mathrm{C}}\right)$ match well with those obtained by spectrophotometric measurement as shown in Figure 6 and Figure 7. Based on these data, we can say that our extract is not cytotoxic to RBCs.

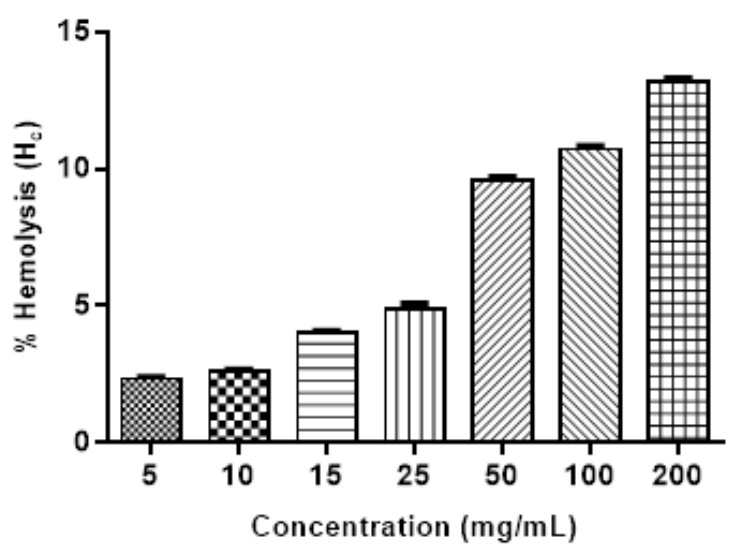

Figure 6.

Haemolytic effect of aqueous leaf extract of $L$. guyonianum measured by cell count $\left(\mathrm{H}_{\mathrm{C}}\right)$ Different letters represent significant differences $\mathrm{p}<0.05$ (Tukey test)

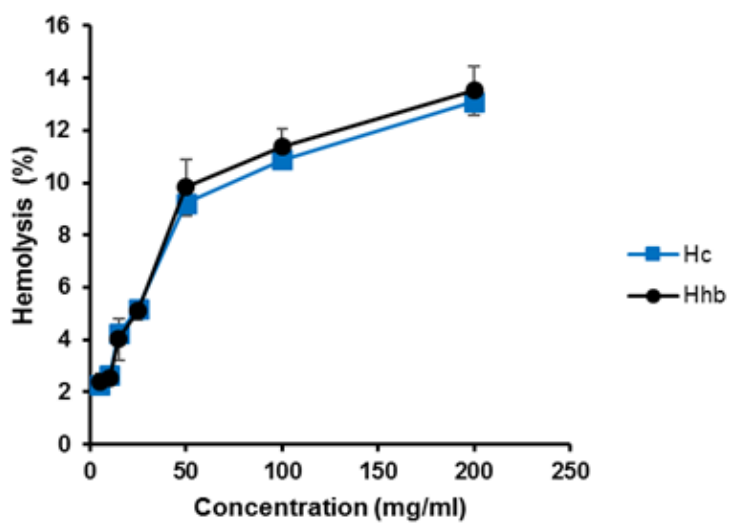

Figure 7.

Evolution of haemolysis percentages measured by spectrophotometry $\left(\mathrm{H}_{\mathrm{Hb}}\right)$ and cell count $\left(\mathrm{H}_{\mathrm{C}}\right)$

Similar studies on the haemolytic potency of the methanolic extracts of 9 plants (Calotropis procera, Paronychia argentea, Paronychia chlorothyrsa, Morettia canescens, Haloxylon scoparium, Thymelaea hirsuta, Tamarix aphylla, Daphne gnidium and Arthrophytum schmittianum) harvested from arid zones and sub-arid regions of Algeria have been carried out [29]. The range of concentrations of the aforesaid extracts ranged 
between 50 and $500 \mu \mathrm{g} / \mathrm{mL}$. The highest haemolytic activity was observed with the Saharan species $M$. canescens $(14.80 \%)$. On the other hand, no haemolytic activity was observed with $P$. chlorothyrsa extract. Our results are comparable to those of Chaouche $e t$ al. [10] for the methanolic extract of the root bark of Juniperus oxycedrus, which for concentrations of $5,10,15$ and $20 \mathrm{mg} / \mathrm{mL}$, showed percentages of haemolysis of 2.40, 2.94, 4.09 and $4.37 \%$, respectively. In addition, the incubation of the previous 4 extracts of the root bark of $J$. oxycedrus with human erythrocytes for one hour led to haemolytic activities between $2.05 \%$ and $4.37 \%$ [10].

The results of the haemolytic effect of the various racquet extracts of Opuntia ficus indica, showed that this plant has a low toxic effect against isolated erythrocytes compared to total haemolysis. The doses causing 50\% haemolysis ranged from 0.389 (acetone extract) to $1.587 \mathrm{mg} / \mathrm{mL}$ (butanolic extract), whereas the dose of the aqueous extract was $0.606 \mathrm{mg} / \mathrm{mL}$ [20]. Zubair et al. also reported that the haemolytic potential of the various leaf extracts of Smilax macrophylla (Smilacaceae) was low and did not exceed 8.48\% [46]. Most recently, Surendra et al. reported that Moringa oleifera skin extract had no toxicity to RBCs [38].

RBCs were chosen as a cellular model for the in vitro study of cytotoxicity because of their isolation facilities and simplicity. Therefore, the results of the haemolytic study showed that $L$. guyonianum aqueous leaf extract has a very low or negligible toxic effect against the human RBCs. However, further studies on a wider range of cells will be needed to confirm the results of this research.

\section{Conclusions}

This study provides important data on the acute toxicity profile and cytotoxicity test of the aqueous extract of L. guyonianum. In the acute toxicity assays, no mortality or specific toxic signs were observed in female mice after oral administration of the extract at all tested doses. The extracts did not produce any remarkable histopathological signs or serum biochemical alteration. The $\mathrm{LD}_{50}$ can then be estimated to be greater than $5000 \mathrm{mg} / \mathrm{kg}$ bw. This value is relatively high inducing a safety use of this extract, which can be considered a non-toxic substance. The recommended dose used in humans will be a maximum of $500 \mathrm{mg} / \mathrm{kg}$ bw. The cytotoxic study showed a slight haemolysis of $13.5 \%$ obtained for an extreme concentration of $200 \mathrm{mg} / \mathrm{mL}$, showing no cytotoxic activity of the extract against the RBCs. Hence, the extract can be used without any health risk both in folkloric medicine as an oral anti-infective and for pharmaceutical formulations. However, further toxicity studies should be done to further ascertain the safety of the users of this plant. Finally, our results should be very useful for any future in vivo and clinical study of this medicinal halophyte plant.

\section{Conflict of interest}

The authors declare no conflict of interest.

\section{References}

1. Adouane S, Ethnobotanical study of medicinal plants in the southern region of Aurès. Doctoral Dissertation, Université Mohamed Khider, Briska, 2016; (available in French).

2. AFSSAP, Clinical trials of the first administration in humans as a single dose of a drug. Choice of the first dose, dose progression and administration protocol to volunteers. Agence Française Sanit, 2006; 1-5, (available in French).

3. Amacher DE, A toxicologist's guide to biomarkers of hepatic response. Hum Exp Toxicol., 2002; 21(5): 253-262.

4. Antonelli-Ushirobira TM, Blainski A, Fernandes HG, Moura-Costa GF, Costa MA, Campos-Shimada LB, Salgueiro-Pagadigorria CL, Kaneshim EN, Becker TCA, Leite-Mello EVS, de Mello JCP, Acute toxicity and long-term safety evaluation of the crude extract from rhizomes of Limonium brasiliense in mice and rats. J Ethnopharmacol., 2015; 174: 293-298.

5. Belfar A, Hadjadj M, Dakmouche M, Bensaci C, Ghiaba Z, Cherbi Y, Antibacterial activity of Limoniastrum guyonianum medicinal plant used in Algerian traditional medicine. Der Pharma Chem., 2016; 8(21): 31-34.

6. Benkhaled A, Senator A, Effects of aqueous leaf extract of Limoniastrum guyonianum pretreatment on nickel induced acute heamatotoxicity in male mice. Glob Veterinaria, 2015; 15(5): 493-497.

7. Bouzidi A, Benzarti A, Arem AEl, Mahfoudi A, Hammani S, Gorcii M, Mastouri M, Hellah AN, Mighri $\mathrm{Z}$, Chemical composition, antioxidant and antimicrobial effects of Tunisinian Limonistraum guyonianum Durieu ex Boiss extracts. Pak J Pharm Sci., 2016; 29(4): 1299-1305.

8. Center SA, Elston TH, Rowland PH, Rosen DK, Reitz BL, Brunt JE, Rodan I, House J, Bank S, Lynch LR, Dring LA, Levy JK, Fulminant hepatic failure associated with oral administration of diazepam in 11 cats. J Am Vet Med Assoc., 1996; 209(3): 618-625.

9. Chaieb M, Boukhris M, Succinct and illustrated flora of the arid and Saharan zones of Tunisia. Assoc. Prot. Nat. Environment, L'or du temps, Sfax, 1998; (available in French).

10. Chaouche TM, Haddouchi F, Atik-Bekara F, Ksouri R, Azzi R, Boucherit Z, Tefiani C, Larbat R, Antioxidant, haemolytic activities and HPLC-DAD-ESI-MSn characterization of phenolic compounds from root bark of Juniperus oxycedrus subsp. oxycedrus. Ind Crops Prod., 2015; 64: 182-187.

11. Chaumont J, Mellet-Clerc J, Phyto-aromatherapy applied to dermatology. Lavoiser, 2011; (available in French).

12. Chehma A, Djebar MR, The spontaneous medicinal species of the northern Algerian Sahara: spatialtemporal distribution and etnobotanical study. Synthèse Rev Sci Technol., 2008; 17: 36-45, (available in French). 
13. Conseil Canadien de Protection des Animaux, Handbook on the care and use of experimental animals. Ottawa, 1993; (available in French).

14. Debouba M, Zouari S, Zouari N, Evaluation of antioxidant status of two Limoniastrum species growing wild in Tunisinian salty lands. Antioxidants, 2013; 2(3): 122-131.

15. El Rhaffari L, Zaid A, Practice of herbal medicine in the south-east of Morocco (Tafilafet). Empirical knowledge for a renovated pharmacopoeia, in Proceedings of the $4^{\text {th }}$ European Congress of Ethnopharmacology, 2002; 293-318, (available in French)

16. Fintelmann V, Weiss RF, Practical handbook of herbal medicine. Vigot, 2004; (available in French).

17. Graça C, Freitas CS, Baggio CH, Dalsenter PR, Marques MCA, Mikania laevigata syrup does not induce side effects on reproductive system of male Wistar rats. J Ethnopharmacol., 2007; 111(1): 29-32.

18. Hadjadj S, Bayoussef Z, El Hadj-Khelil AO, Beggat H, Bouhafs Z, Boukaka Y, Khaldi IA, Mimouni S, Sayah F, Ethnobotanical study and phytochemical screening of six medicinal plants used in traditional medicine in the Northeastern Sahara of Algeria (area of Ouargla). J Med Plants Res., 2015; 9(41): 1049-1059.

19. Halim SZ, Abdullah NR, Afzan A, Abdul Rashid BA, Jantan I, Isamil Z, Acute toxicity study of Carica papaya leaf extract in Sprague Dawley rats. J Med Plants Res., 2011; 5(10): 1867-1872.

20. Halmi S, Botanical and phytochemical study: biological and pharmacological approach of Opuntia ficus-indica. Doctoral Dissertation, Université des Frères Mentouri, Costantine, 2015; (available in French).

21. Hodge HC, Sterner JH, Tabulation of toxicity classes. Am Ind Hyg Assoc Q., 1949; 10(4): 93-96.

22. Kew MC, Serum aminotransferase concentration as evidence of hepatocellular damage. Lancet, 2000; 355(9204): 591-592.

23. Krifa M, Alhosin M, Muller CD, Gies JP, ChekirGhedira L, Ghedira K, Mély Y, Bronner C, Mousli M, Limoniastrum guyonianum aqueous gall extract induces apoptosis in human cervical cancer celle involving $\mathrm{p} 16^{\mathrm{INK} 4 \mathrm{~A}}$ re-expression related to UHRF1 and DNMT1 down-regulation. $J$ Exp Clin Cancer Res., 2013; 32(1): 30: 1-10.

24. Krifa M, Bouhlel I, Ghedira-Chekir L, Ghedira K, Immunomodulatory and cellular anti-oxidant activities of an aqueous extract of Limoniastrum guyonianum gall. J Ethnopharmacol., 2013; 146(1): 243-249.

25. Krifa M, Bouhlel I, Skandrani I, Ghedira-Chekir L, Ghedira K, Antioxidant, mutagenic and antimutagenic activities of an aqueous extract of Limoniastrum guyonianum gall. Drug Chem Toxicol., 2014; 37(1): 76-82.

26. Krifa M, Pizzi A, Mousli M, Chekir-Ghedira L, Leloup L, Ghedira K, Limoniastrum guyonianum aqueous gall extract induces apoptosis in colorectal cancer cells by inhibiting calpain activity. Tumor Biol., 2014; 35(8): 7877-7885

27. Krifa M, Skandrani L, Pizzi A, Nasr N, Ghedira Z, Mustapha N, Ghedira K, Chekir-Ghedira L, An aqueous extract of Limoniastrum guyonianum gall induces anti-tumor effects in melanoma-injected mice via modulation of the immune response. Eur J Cancer, 2014; 69: 76-85.

28. Médaille C, Briend-Marchal A, Practical guide to veterinary laboratory analyses. Editions Med'Com, 2008; (available in French).

29. Mohammedi Z, Atik F, Hemolytic activity of different herbal extracts used in Algeria. Ind J Pharm Sci Res., 2014; 5(8): 495-500.

30. OECD, Guidance document on acute toxicity testing. Series on testing and assessment, 2001; 1-24.

31. OECD, Test No. 420: Acute oral toxicity - Fixed dose procedure, OECD Guidelines for the testing of chemicals, Section 4. OECD, 2002.

32. Ozer J, Ratner M, Shaw M, Bailey W, Shomaker S, The current state of serum biomarkers of hepatotoxicity. Toxicology, 2008; 245(3): 194-205.

33. Pour BM, Latha LY, Sasidharan S, Cytotoxicity and oral acute toxicity studies of Lantana camara leaf extract. Molecules, 2011; 16(5): 3663-3674.

34. Powell WA, Catranis CM, Maynard CA, Design of self-processing antimicrobial peptides for plant protection. Lett Appl Microbiol., 2000; 31: 163-168.

35. Sandeep G, Dheeraj A, Sharma NK, Jhade D, Bharti A, Effect of plumbagin free alcohol extract of Plumbago zeylanica Linn. root on reproductive system of female Wistar rats. As Pac J Trop Med., 2011; 4(12): 978-984.

36. Șlencu BG, Ciobanu C, Cuciureanu R, Anton A, Ciobanu S, Solcan G, Solcan C, Protective effects of selenium on hepatotoxicity caused by subacute experimental combined exposure to cadmium and lead in rats. Farmacia, 2018; 66(5): 866-878.

37. Solomon FE, Sharada AC, Devi PU, Toxic effects of crude root extract of Plumbago rosea (Rakta chitraka) on mice and rats. J Ethnopharmacol., 1993; 38(1): 79-84.

38. Surendra TV, Roopan SM, Arasu MV, Al.Dhabi NA, Sridharan M, Phenolic compounds in drumstick peel for the evaluation of antibacterial, hemolytic and photocatalytic activities. J Photochem Photobiol B., 2016; 161: 463-471.

39. Tang XH, Gao J, Xu LZ, Tang YH, Zhao XN, Micheal $\mathrm{L}$, Mitochondrial modulation is involved in the hepatoprotection of Limonium sinense extract against liver damage in mice. J Ethnopharmacol., 2008; 120(3): 427-431.

40. Todea DA, Cadar O, Simedru D, Roman C, Tanaselia C, Suatean I, Naghiu A, Determination of major-totrace minerals and polyphenols in different apple cultivars. Notulae Botanicae Horti Agrobotanici, 2014; 42(2): 523-529.

41. Trabelsi N, Oueslati S, Henry-Vitarc C, Waffo-Téguo P, Medini F, Mérillon J, Abdelly C, Ksouri R, Phenolic content and biological activities of Limoniastrum guyonianum fractions obtained by centrifugal partition chromatography. Ind Crops Prod., 2013; 49: 740-746.

42. Trabelsi N, Waffo-Téguo P, Snoussi M, Ksouri R, Mérillon JM, Smaoui A, Abdelly C, Variability of phenolic composition and biological activitie of two Tunisian halophyte specie from contrasted regions. Acta Physiologiae Plantarum, 2013; 35: 749-761.

43. Trabelsi N, Oueslati S, Ksouri R, Nassra M, Marchal A, Krisa S, Abdelly C, Mérillon J, Waffo-Téguo P, The antioxidant properties of new dimer and two 
monomers isolated from Limoniastrum guyonianum. Food Chem., 2014; 146: 466-471.

44. Willard MD, Twedt DC, Gastrointestinal, pancreatic and hepatic disorders. In: Small animal clinical diagnosis by laboratory methods. Elsevier, 2012; 191-225.

45. Ziani BEC, Calhelha RC, Barreira JCM, Barros L, Hazzit M, Ferreira ICFR, Bioactive properties of medicinal plants from Algerian flora: selecting the species with the highest potential in view of application purposes. Ind Crops Prod., 2015; 77: 582-589.

46. Zubair M, Bibi Z, Rizwan K, Rasool N, Zahoor AF, Riaz M, In vitro antimicrobial and haemolytic studies of Bambusa arundinaceae leaves. J Appl Pharm Sci., 2013; 3(4): 111-115. 